\title{
MONOPOLY IN LAW AND ECONOMICS
}

\author{
By EDWARD S. MASON†
}

I.

THE TERM monopoly as used in the law is not a tool of analysis but a standard of evaluation. Not all trusts are held monopolistic but only "bad" trusts; not all restraints of trade are to be condemned but only "unreasonable" restraints. The law of monopoly has therefore been directed toward a development of public policy with respect to certain business practices. This policy has required, first, a distinction between the situations and practices which are to be approved as in the public interest and those which are to be disapproved, second, a classification of these situations as either competitive and consequently in the public interest or monopolistic and, if unregulated, contrary to the public interest, and, third, the devising and application of tests capable of demarcating the approved from the disapproved practices. But the devising of tests to distinguish monopoly from competition cannot be completely separated from the formulation of the concepts. It may be shown, on the contrary, that the difficulties of formulating tests of monopoly have definitely shaped the legal conception of monopoly.

Economics, on the other hand, has not quite decided whether its task is one of description and analysis or of evaluation and prescription, or both. With respect to the monopoly problem it is not altogether clear whether the work of economists should be oriented toward the formulation of public policy or toward the analysis of market situations. The trend, however, is definitely towards the latter. The further economics goes in this direction, the greater becomes the difference between legal and economic conceptions of the monopoly problem. Lawyers and economists are therefore rapidly ceasing to talk the same language.

Twenty years ago this was not the case. In 1915 there appeared in the Journal an article on the Trust Problem which quoted the opinions of eminent economists on the significance of a contemporary "trust" decision. ${ }^{1}$ The point the author was trying to make, flattering indeed to the study of economics, was "that in cases of this character no decision can be legally sound that is not fundamentally correct from an economic point of view." 2 The question posed to the economists was the import in

†Professor of Economics, Harvard College. The author wishes to acknowledge his indebtedness to the A. W. Shaw Fund and to the Harvard University Committee on Research in the Social Sciences for assistance in financing a larger study on monopoly problems of which this is a part.

1. Friedman, The Trust Problem in the Light of Some Recent Decisions (1915) 24 Y ALE L. J. 488.

2. Id. at 493. 
terms of monopoly of the production by the International Harvester Company of $65-85 \%$ of the national output of certain types of harvesting machinery. ${ }^{3}$ While the answers may or may not have been helpful in the formulation of legal opinion, it is a point of peculiar interest that the economists conceived the problem in much the same way as the courts. It was not monopoly as an analytical concept but monopoly injurious to the public interest which colored their thinking. The economists' emphasis on free entry into the industry as characteristic of competition and restriction of entry as the differentia specifica of monopoly was in complete harmony with the judicial predilection. Monopoly was thought of as the antithesis of free competition, unregulated monopoly was always and necessarily a public evil, the nature of monopoly was to be found mainly in restrictions on trade, and its remedy was, in the Wilsonian phrase, "a fair field with no favor."

Since that time, particularly in recent years, economic thinking on the subject of monopoly has taken a radically different trend. Much more attention has been given to the shaping of the concept of monopoly as a tool of economic analysis rather than as a standard of evaluation in the judgment of public policy. Some of the consequences of this trend have been the focussing of attention on the problems of the individual firm rather than those of the industry, a recognition of monopoly elements in the practices of almost every firm, a recognition of the impossibility of using the fact of monopoly as a test of public policy, and a growing awareness of the necessity of making distinctions between market situations all of which have monopoly elements. The trend has led to a split between the approach to the monopoly problem in the law and economics which requires bridging by interpretative work of a high order. The following pages are not concerned primarily with this task but rather with an economist's impression of the divergence between the present legal and economic concepts of monopoly.

\section{II.}

The elements out of which both law and economics have built their ideas of monopoly are restriction of trade and control of the market. These elements are of course not independent. Restrictions of trade of various sorts are familiar devices for securing control of the market; control of the market may be used, as in predatory competition, to restrict trade and competition. Nevertheless, restraints of trade can exist without anything that the courts would be willing to call control of the market. And, control of the market, in the economic sense, can exist independently of any practice which the law would call a restraint of trade.

3. Id. at $502,503$. 
It is also important at this point to understand the content of several other basic concepts. The antithesis of the legal conception of monopoly is free competition, understood to be a situation in which the freedom of any individual or firm to engage in legitimate economic activity is not restrained by the state, by agreements between competitors or by the predatory practices of a rival. But free competition thus understood is quite compatible with the presence of monopoly elements in the economic sense of the word monopoly. For the antithesis of the economic conception of monopoly is not free but pure competition, understood to be a situation in which no seller or buyer has any control over the price of his product. Restriction of competition is the legal content of monopoly; control of the market is its economic substance. And these realities are by no means equivalent.

An illustration of the application of these concepts is presented by the facts of the Cream of Wheat case. ${ }^{4}$ The Cream of Wheat Company bought purified middlings, a high-grade by-product of wheat, and, "without submitting them to any process or treatment, without adding anything to them, it puts up the middlings which it selects in packages and offers its selection to the trade under the name of 'Cream of Wheat'." The court was unable to see either control of the market or restriction of trade in this practice. "The business of the defendant is not a monopoly, or even a quasi-monopoly. Really it is selling purified wheat middlings and its whole business covers only about 1 per cent. of that product. It makes its own selection of what by-products of the middling process it will put up, and sells what it puts up under marks which tell the purchaser that these middlings are its own selection. It is open to Brown, Jones and Robinson to make their selections out of the other 99\% of purified middlings and put them up and sell them; possibly one or more of them may prove to be better selectors than the defendant, or may persuade the public that they are." 8

An economist, on the other hand, would be inclined to say that the product sold is not wheat middlings but Cream of Wheat, and that the Cream of Wheat Company exercises some monopolistic control of the market unless, and this is unlikely, the number and quantity of substitute products is such as to render the price independent of the quantity sold. He would add that it does not follow that the market control incident to such a monopoly position is contrary to public policy. Furthermore he would consider monopoly of the production of Cream of Wheat as perfectly compatible with competition on the part of actual or potential producers of substitute products.

4. Great Atlantic and Pacific Tea Company v. Cream of Wheat Company, 227 Fed. 46 (1915).

5. Id. at 47 .

6. Id. at 48 . 
The economists' emphasis is on control of the supply or price of a product. And "product" is defined in terms of consumer choice, for if consumers find that the goods sold by two competing dealers are different, they are different for purposes of market analysis regardless of what the scales or calipers say. Some control of the market exists whenever a seller can, by increasing or diminishing his sales, affect the price at which his product is sold. Since, outside the sphere of agricultural and a few other products, almost every seller is in this position, it is easy to see that if monopoly is identified with control of the market, monopolistic elements are practically omnipresent. This is the logical conclusion, it is submitted, where the emphasis is laid upon control of the market and the monopoly concept is considered as a tool of analysis only, unrelated to public policy. But if monopoly is considered to be a standard of evaluation useful in the administration of public policy then other considerations must be involved.

It is so used in the law. Although the history of the term's legal usage is filled with references to control of the market as evidence of monopoly, various factors, principally the difficulties of devising tests of the reasonableness of price and output controls, have focussed the attention of courts on another element, restriction of trade, as the decisive consideration. The development of this idea may be seen in the sources of the present law of monopoly and competition, which are, according to Jervey and Deák, to be found in "(A) the Statute against Monopolies and $D^{\prime}$ Arcy $v$. Allein; (B) the old English statutes against forestalling and engrossing; (C) the judicial adaptation of the ancient law on restraint of trade to the combination acting as a unit of controlled parts; and (D) the law of conspiracy as applied to the illegal end of suppression of competition, with particular reference to labor conspiracies insofar as they were seen as restraints on the market."7

It is clear from the Statute of Monopolies ${ }^{8}$ and from contemporary definitions that monopoly meant exclusion of other producers or sellers by a dispensation from the sovereign granting sole rights to some person or persons.". Although D'Arcy v. Allein" declared the "inseparable incidents" of monopoly to be (1) the raising of the price of the product, (2) the deterioration of its quality, and (3) the "impoverishment of

7. Huger W. Jervey and Francts Deak, The Case of Mlo:iopoly v. CormeTITION, (Mimeo., 1934).

8. $21 \mathrm{Jac}$ I, c. 3. (1623).

9. Coke defined monopoly in this way: "An institution, or allowance by the ling, by his grant, commission, or otherwise, to any person or persons, bodies politique or corporate, of, or for the sole buying, selling, making, working, or using, of anything, whereby any person, or persons, bodies politique or corporate, are sought to be restrained of any freedom or liberty that they had before, or hindered in their lawful trade." 3 INSTITUTES No. 181.

10. 11 Co. $84 b, 74$ Eng. Reprint 1131 (1602). 
divers artificers and others" because of exclusion from their accustomed trades, a monopoly was considered to exist whether or not these "incidents" followed. It was not incumbent upon the courts to show that prices had actually been raised or quality of the product deteriorated in order to be able to hold that a monopoly existed contrary to the common law. ${ }^{11}$ Monopoly meant exclusion from a certain trade by legal dispensation and no examination of control of the market was necessary to establish this fact.

The injuries inflicted by forestalling, regrating and engrossing were in the main conditioned and limited by an early and now obsolete system of distributing and marketing goods, principally foodstuffs. Laws were found necessary to prohibit the spreading of false reports as to the state of the market (regrating), to prohibit the purchase of victuals on the way to market for purposes of resale (forestalling), and to prohibit the cornering of the available supply of an article (engrossing). ${ }^{12}$ It is true that engrossing in particular was an act undertaken to secure what an economist would call control of the market. But in the absence of a combination, of attempts to exclude competitors, or of other overt acts, it was difficult for the courts to find evidence of control of the market. There is no obvious answer to the question of how large a share of the available supply of an article an individual must purchase before he is guilty of engrossing. If, on the other hand, the engrossing were accomplished by a combination, particularly if the combination attempted to exclude competitors, the problem appeared to be more simple. ${ }^{13}$ Conspiracy frequently accompanied engrossing in the early cases and was rarely absent in the later ones. In no engrossing case that has come before Anglo-Saxon courts in the last hundred and fifty years, so far as I am aware, has a court undertaken to discover the existence of engrossing by examining the control of the engrosser over the price. What cases there are, and they have been few, have been complicated by the presence

11. As a matter of fact it is quite possible that a monopoly dispensation would not give to its holder control of the market in the sense of ability to raise price or to lower the quality of the product. Whether it did or not would depend, in cconomic jargon, on the elasticity of demand for that product, and this in turn would be influenced by a number of factors including the existence of effective substitutes.

12. See Jones, Historical Development of The Law of Business Competition (1926) 35 YALE L. J. 905, at 907 et seq.

13. "To gain a monopoly on a local market a common, organized action, in other words a cartel of the most powerful competitors, often became a necessity. The fact that competitors acted in agreement when engrossing the market is expressed in the English anti-monopolistic legislation by the significant term conspiracy. This word was first used in this connection in the Statute of 1353 [a Forestalling Statute, of 27 Edw. III], and reappears continually in the anti-monopolistic statutes. From here it passes over to the American anti-trust legislation, being thus a continuation of the old monopoly prohibitions." Pictrowski, Cartels aNd Trusts (1933) 148, quoted in Jervey AND DEAK, op. cit. supra, note 7. 
of combinations or conspiracies to restrain trade. The courts have found monopoly because of conspiracy and the exclusion of others from the market rather than control of the market. It is doubtful whether the act of engrossing itself, in the absence of a conspiracy to exclude competitors, would carry any monopoly connotation in the law. Consequently it seems doubtful whether the ancient law respecting engrossing, forestalling and regrating has made much of a contribution to present legal concepts of monopoly.

In a somewhat different status in this respect is the law on restraint of trade. The question of restraints originally came before the courts in cases involving the sale of a business in which, as an incident to the sale, the seller contracted not to compete with the buyer. Until sometime in the 17th century the courts uniformly held such contracts unenforceable, the basis of the rule being "that public policy demands from every man the free exercise of his trade in the public interest." 14 Did public policy demand the free exercise of trade because in the absence of such free exercise there would be a control of the market?

Restrictive covenants, if enforceable, certainly may lead to control of a local market, but control of the market is not dependent on the existence of such contracts. Doctors, lawyers, or tradesmen dealing in a particular type of article may be, and frequently were in the period in which restrictive covenants were unenforceable, the sole practitioners of their profession or trade in a given locality possessing a control of the local market. Yet this fact does not appear to have led to legislative or judicial concern. It appears more consistent with the early decisions to say that restrictive covenants were feared because one who contracted himself out of a livelihood might become a public charge.

The development in the 17th and 18th century of the doctrine of "reasonable restraints," as applied to restrictive covenants in connection with the sale of a business, does not seem to have involved any closer consideration of the monopoly problem. Although it is sometimes said, ${ }^{15}$ or implied, that the reasonableness which concerned the courts in such contracts was understood not only in relation to the interests of the contracting parties but also to the public interest in prevention of control of the market, it is difficult to substantiate this view by an appeal to the decisions. ${ }^{16}$ The application of the doctrine of reasonableness to the interests of the contracting parties is clear. The interest of the buyer was a property interest, that the value of the purchased business not be lessened by competition from the seller in the immediate vicinity, while that of the seller was not only a property interest, since he obtained

14. Cooke, Legal Rule and Economic Function (1936) 46 Ecow. J. 21.

15. See, e.g., Pope, The Legal Aspects of Monopoly (1907) 20 Hanv. L. Rev. 167 ; Cooke, op. cit. supra, note 14.

16. Mitchel v. Reynolds, 1 P. Wms. 181 (1711). 
through the sale the full value of the "good will" of the business, but also an interest in safeguarding the possibility of continuing somewhere and at some time his trade or profession. The language of the courts indicates that the public interest was considered affected when the public was deprived by such a contract of a source of supply without justification, i.e., when such a deprivation was unnecessary to the protection of the private interests involved in the contract. This protection of the public interest was levelled primarily not against monopolistic control of the market but against the loss to the common weal of the services of a productive agent. There is no evidence that the courts examined the data relevant to the question whether such a contract might lead to control of the market. If any monopoly consideration was involved, it was monopoly in the sense of restriction of competition, not of control of the market.

If the test of reasonableness referred to the extent of competition or control of the market which would result from the restrictive contract, might we not have expected the courts to compare the market situation in the locality affected by the contract with the market situations in other localities? If the restrictive covenant reduced the number of possible competitors by one, this might have a very different effect on control of the market in a locality in which competitors were many from its effect in a locality in which only one remained. There is not much evidence, however, that the courts considered the easily available facts relative to extent of market control, and the cause seems to be that the "reasonableness" with which they were concerned in cases involving restrictive covenants was rarely, if ever, related to the monopoly problem.

The gradual relaxation of the law on restrictive covenants is easily understood with reference to the interests of the contracting parties and requires no examination of the changes in the scope of market control. With the increase in economic opportunities incident to increasing division of labor the means of gaining a livelihood open to a seller of a business expanded, and the restrictions imposed on his activities by these covenants became less serious. On the other hand, with the growth of transportation facilities the area within which the competition of the seller might lessen the value of what he has sold had increased. For both these reasons the scope permitted restraints of trade of this sort has been enlarged. ${ }^{17}$ Moreover, whether or not the establishment of a competing enterprise in a given locality was likely to affect the value of the business sold, and whether or not a limitation in trading in a given locality was likely to deprive a man of the means of earning his livelihood and the public of the fruit of his activity were questions to which common experience might be said to provide a tolerably satisfactory

17. Handler, Restraint of Trade, (1934) 13 Encyc. Soc. Sctences 339. 
answer. The question whether the elimination of one unit of competition would result in control of the market, however, could hardly be answered without an examination of the number of competitors left in the restricted area and of the behavior of prices. To such an examination the courts were hesitant to proceed.

The application of the rule of reason to contracts between competitors designed solely to limit competition among themselves stands on different ground. It is frequently said that, as distinguished from restrictive covenants connected with the sale of a business, the interests of the contracting parties are here not at issue since such contracts will not be entered into unless there is prospect of gain to all from the limitation. ${ }^{18}$ While this may or may not be true, if the rule of reason is to be applied to such cases, it must be applied on different grounds, or it must be a different rule than that used in the older cases of restraint of trade. For in this type of contract the public interest in the monopoly problem is paramount, and the question of the private interests of the individual contractors is only secondary.

The disposition of American courts has been, at least until very recently, to hold all contracts for division of territory, pooling, fixing of prices, common marketing control of supply, or which restrict the freedom of the contractors to compete in other ways, unenforceable and, since the Sherman Act, illegal. The opinions of the court in these cases constantly refer to monopoly in the sense of control of the market, but little examination of evidence pertinent to the question of market control is ever undertaken. The test of monopoly, or attempt of monopoly, is here restriction of competition. American courts have in this class of cases been willing to accept the contract itself as evidence of restriction and, consequently, of an attempt to monopolize, without inquiring further into the question of how great a control of the market is secured to the contracting parties. ${ }^{19}$ The rule of reason enunciated with much fanfare by Chief Justice White purporting to provide a standard of judgment dividing those contractual restrictions which are in the public interest from those which are not has had, at least until the Appalachians

18. Pope, op. cit. supra, note 15 ; Cooke, op. cit. supra, note 14.

19. In another class of cases, however, dealing principally with trade association activities, the Courts have drawn a distinction between limitation of competition and a regulation by business agreement of competitive methods. Nowhere is this distinction better expressed than by Justice Brandeis in Board of Trade of the City of Chieago et al. v. United States, 246 U. S. 231, at p. 239. "Every agreement concerning trade, every regulation of trade, restrains. To bind, to restrain, is of the very essence. The true test of legality is whether the restraint imposed is such as merely. regulates and perhaps thereby promotes competition or whether it is such as may suppress or even destroy competition." 
Coal case $^{20}$ in 1933, a much narrower application than might have been expected.

The British courts, confronted with the same problem of applying a rule of reason to contracts between competitors designed to limit competition, have returned a somewhat different answer. They have tended to accept every contract designed to limit competition among the contracting competitors as reasonable in the absence of intention or actual attempt to injure or destroy a competitor. ${ }^{21}$ On the other hand, the trend of American opinion has been to regard all such contracts as unreasonable restraints of trade. In neither case has the rule of reason been given any intelligible content in terms of control of the market despite the frequency with which this phrase has graced judicial utterances.

Cases involving a union between competitors accomplished by amalgamation or fusion or merger have in this country most frequently involved the application of the rule of reason, and it is in these cases that the characteristic legal conception of monopoly is most evident. An amalgamation of competing firms may, and ordinarily does, take place for reasons other than to secure control of the price of the articles produced or sold by these firms. The courts could not, therefore, plausibly assume, as they did in the case of contracts to limit competition, that all amalgamations were prima facie evidence of an attempt to monopolize.

Since under the Sherman Act both the contract and the combination as an attempt to monopolize or restrain trade were illegal, some way had to be found of making the law on combinations equivalent to the law on contracts limiting competition. If monopoly had meant to the courts control of the market, some such equivalence might well have been found, although the problem would have been, and is, difficult. Yet the sources of evidence of control of the market are known: the behavior of prices and outputs, the relation of prices and costs, profits before and after the combination, share of the market controlled, the existence of business practices such as price discrimination, price stabilization and many others. The evidences of a control of the market

20. Appalachian Coals, Inc. v. United States, 288 U. S. 344 (1933).

21. See the dictum of Lord Parker in the Adelaide case: " . . . it is clear that the onus of showing that any contract is calculated to produce a monopoly or enhance prices to an unreasonable extent will be on the party alleging it, and that if once the court is satisfied that the restraint is reasonable as between the parties the onus will be no light one." Attorney-General of Australia v. Adelaide Steamship Co., 1913 A. C. 781, 796. Such a contract may produce an "unreasonable" control of the market but the British courts have rarely found one. A contract which restricts competition by the destruction of a competitor's market is a different matter. Here there is an overt act, an obvious restraint of trade, partaking of the nature of conspiracy, that does not compel the courts to examine the behavior of prices and outputs which are the most obvious sources of information concerning control of the market. 
established by combination would be found in the same sort of data as in control established by contract, and a rule of reason which set up as its standard control of the market would have yielded approximately the same results in both types of cases.

By monopoly, however, the courts did not mean control of the market but restriction of competition. While a contract between competitors designed to limit competition carries the evidence on its face of an attempt to monopolize, a merger between competitors does not, so that the courts had perforce to enquire, (1) into the intentions of the merging interests, and (2) into such acts of the merger as might indicate restriction of outside competition. If the intention behind a merger were control of the market it is unlikely that it would be communicated to the courts, and since the only evidences capable of indicating intention to control the market were ignored we may conclude that the courts found the presence of monopoly in other ways. If the manifestation of the intention to limit the competition of outsiders took the form of overt acts such as local price discrimination, espionage, or securing of railway rebates, the courts could find evidence of restrictions directly relevant to their conception of monopoly. As a matter of fact it is clear that this was the direction taken in the judicial application of the rule of reason. The size of the combination or its share of the total output of a product became important only when accompanied by predatory practices affecting the freedom of others to compete. In the words of one commentator it had become clear by 1918 "that the Sherman Act had evolved from an anti-trust act into an act relating to the legal control of competitive methods." 22 Since monopoly meant restriction of competition rather than control of the market, this evolution was only logical.

The decision in the Standard Oil-Vacuum merger in 1931, it is true, gave somewhat more consideration to the problem of market control than has been usual in merger cases. ${ }^{23}$ The court took into account (1) the merged concerns' share of sales of their various products in the local market, (2) the state of intercompany competition in the New England market, the number and size of companies, the area of their operations, and recent changes in the market position of the various companies, and (3) potential competition. Despite the advance, the dicta of Judge Kimbrough Stone in this case cannot be said to indicate a clear conception of monopoly in terms of market control. "Competition," he declares,

"is the antithesis of monopoly. In a sense, any elimination of competition is a movement in the general direction of monopoly. But

22. McLaughlin, Legal Control of Compelitive Methods (1936) 21 Iowa L. Rev. 280.

23. United States v. Standard Oil Co. of N. J., 47 F. (2d) 283 (C. C. A. 2d, 1931). For another realistic analysis of a market situation, see International Shos Co. v. Federal Trade Commission, 29 F. (2d) 518 (C. C. A. 2d, 1931). 
competition is, in its very essence, a contest for trade, and any progress or victory in such contest must lessen competition. . . . It is only when this lessening is with an unlawful purpose. or by unlawful means, or when it proceeds to the point where it is or is threatening to become a menace to the public, that it is declared unlawful. . . The point of danger is reached when monopoly is threatened."

We might now expect some indication of tests which the court will apply to determine when monopoly is threatened. But the opinion continues, "This threat of monopoly exists, irrespective of intent, whenever competition is lessened to the danger point." In other words monopoly is threatened when "competition is lessened to the danger point." Competition is lessened to the danger point when "monopoly is threatened." 24 Judge Stone in subsequent remarks appears to be able to get no farther forward with this idea and finally falls back on a dictum of Justice Holmes that "a combination in unreasonable restraint of trade imports an attempt to override normal market conditions." 25 Since nothing is more "normal" than monopolistic market conditions, this too does not get us very far.

This summary review of the law of monopoly must lead to the conclusion that whatever are considered to be the evils resulting from monopoly-enhancement of price, deterioration of product, or the likea monopolistic situation, or an attempt to monopolize, is evidenced to the courts primarily, if not exclusively, by a limitation of the freedom to compete. The original meaning of monopoly, an exclusion of others from the market by a sovereign dispensation in favor of one seller, has continued to mean exclusion, in the broad sense of restriction of competition. Although "undue" or "unreasonable" control of the market is constantly inserted in judicial decisions as the meaning of monopoly, the data capable of indicating this control are almost universally ignored by the courts. In this country there has been a growing tendency in the law to declare every contract between competitors which restricts competition unenforceable and, since the Sherman Act, illegal, whatever the extent of the control made possible by the contract. ${ }^{26}$ In the case of

24. United States v. Standard Oil Co. of N. J., 47 F. (2d) 288, at 297 (C. C. A. 2d, 1931).

25. American Column Co., v. United States, 257 U. S. 377 (1921).

26. There is no evidence that the courts in interpreting the Sherman Act and later anti-trust legislation in the light of common law concepts of monopoly and restraint of trade were violating legislative intention or substituting their understanding of the monopoly problem for that of the Congress. On the contrary there is. every reason to believe that the principal acts which the Sherman Act sought to prevent were the predatory practices of combinations which in many cases already enjoyed a commanding control of the market. The particular practices which received special legislative attention were railway rebating, local price-discrimination and price. 
mergers the monopoly or attempt to monopolize is discovered primarily in predatory practices designed to hamper the competition of outsiders and not in control of the market.

\section{III.}

It has been noted above that the elements on which the idea of monopoly has been built both in law and in economics have been control of the market and restriction of competition. If in their development of the law of monopoly the courts have tended to give mere lip service to the former and to identify monopoly with restriction of competition, the principal reasons are probably the following:

(1) The courts have been faced with the necessity of devising and applying to particular situations a standard of evaluation relevant to a vague concept known as the public interest. The injury to numerous private interests, and consequently to the public interest, from predatory attacks on established business enterprises, or from other attempts to restrict competition, was much more direct than that which might possibly be inflicted on buyers or sellers by a control of the market exercised independently of any attempts to restrict competition.

(2) The formulation of a standard of monopoly or monopolizing contrary to the public interest required the selection of tests capable of distinguishing competitive from monopoly situations. If monopoly were conceived as control of the market, the tests must necessarily be related to the behavior of prices, outputs and other variables indicative of control, an exceedingly difficult problem. If, on the other hand, monopoly is identified with restriction of competition, the devising of tests is comparatively simple.

(3) There is reason to believe that in an earlier period control of the market was much more dependent upon restriction of entry and other types of restriction of competition through predatory practices and harassing tactics than at present. The law of monopoly, though directed against restrictions of competition, may once have had more relevance to control of the market than it at present possesses.

(4) Before the Sherman Act monopoly actions were brought, with but few exceptions, before the courts on the suit of private interests. These interests were more likely to be directly affected adversely by

maintenance. The sponsors of the Act announced on many occasions that it was not designed to prevent combinations either of labor or capital, and in answer to the specific question whether an enterprise would be considered a monopoly if, because of superior skill, it alone received all the orders for a particular article, Senator Hoar replied, "The word 'monopoly' is a merely technical term which has a clear and legal significance, and it is this: it is the sole engrossing to a man's self by mears which prevent other men from engaging in fair competition with him." 21 Coza. REc. 3152 (1890). 
predatory practices or attempts at exclusion from the market than by control of prices.

Although these considerations may help to explain the almost complete preoccupation of the courts with restrictions on freedom of competition, it must be recognized that our modern law embraces an antiquated and inadequate conception of the monopoly problem. Attention and criticism has therefore centered around the following aspects of our public policy with respect to monopoly and competition: the tendency of the courts to find illegal every contract limiting competition among the contracting competitors regardless of the effect or probable effect of such a contract on control of the market; the tendency to judge the legality of a combination or merger primarily on the basis of its competitive practices without examination of the extent of its control of the market; the absence of a developed public policy with respect to unfair practices, in particular the unwillingness of the courts to extend the concept of unfair competition beyond injury to a competitor and to take account of the nature of the injury to the public.

The weakness of our public policy is not the result of judicial interpretation but of the inadequacy of legislation. It can only be corrected by legislation which will re-define the monopoly and trade practice problem and provide tests by means of which market situations and business practices considered to be favorable to the public interest can be separated from those that are not. Since Congress has wrestled with this problem, off and on, for fifty years without conspicuous success, it does not appear likely that a ready-made solution can be found close at hand. Certainly economics has none to provide. Nevertheless, the economic approach, which is in some ways very different from the legal, can be utilized in the shaping of a more satisfactory public policy.

For its own purposes economics has found control of the market a much more useful approach to the concept of monopoly than restriction of competition. Some control of the market may be said to exist whenever the share of the sales or purchases made by any one seller or purchaser (or group of sellers or purchasers acting by means of an agreement) is sufficiently large to influence the price of the article sold. In a market from which control is completely absent every seller and buyer, acting independently, could increase or decrease his purchases or sales without appreciable effect on the price. Such markets, which may be said to be purely competitive in the sense of being completely devoid of any element of control over price, are comparatively rare. In most markets some sellers or buyers (or both) exercise some degree of control. Of course such control is perfectly compatible with the existence of some degree of competition. A seller with complete control of the market would be able to determine his price without regard for the 
actions of other sellers or the prices of other products; in other words, he would have no competition. No seller or buyer has such control. All markets, practically speaking, exhibit a fusion of monopoly and competitive elements.

It follows that, if monopoly is identified with control of the market, (a) it is impossible to separate markets into those that are competitive and those that are monopolistic; (b) a public policy which attempted to eliminate all positions of monopoly would confront a problem of impossible scope and complexity. It is, furthermore, by no means clear that the preservation of all the competitive elements and the suppression of all the monopolistic elements would be in the public interest, however conceived. Consequently, the existence of some control of the market is not likely to be in itself a good indication of the necessity or wisdom of applying preventative measures.

Having identified monopoly with control of the market, economics has proceeded further to an examination of certain typical monopoly situations. But the most that can be said of the results of monopoly investigations in economics is that they cast doubts on a number of traditional legal attitudes on the question of monopoly and restraint of trade, and that they emphasize a number of relevant considerations usually neglected by the interpreters of public policy. The significance of the existence of a relatively small number of buyers or sellers is a case in point. If the number of sellers (or buyers) is small enough to induce each seller, before changing his own selling policy, to take account of the probable effect of this change upon the policies of his rivals, the results of joint action by agreement, which might well be illegal, may be accomplished without collusion of any sort. It is quite obvious from the behaviour of cigarette prices that the manufacturers of cigarettes are in something like this situation. No one can change his prices without an overwhelming probability that his rivals will immediately follow suit, and one result is that price changes are very infrequent. To produce many of the consequences of joint action no one seller has to have a preponderant share of the total output; if the number of sellers is relatively small, their individual share of the total output is of secondary importance.

Nor is control of the market to be inferred merely from the number of existing competitors. Potential competition must be considered. Indeed the dicta of many trust cases might be interpreted as indicating a judicial opinion that in the absence of legal restraints or of overt predatory acts against potential competitors, free entry to the market precludes any element of control. Free entry in this legal sense, however, is compatible under certain circumstances with a considerable degree of market control. The capital resources necessary to establish a new 
firm in an effective competitive position may be so large as to eliminate potential competition as a practical consideration. The fact that no new motor car company has been established in the last decade or that no new brand of cigarettes has been able since the war to capture a sizeable share of the market cannot be taken to indicate that no control of the market exists.

The legal significance attached to trade marks and trade names provides another example of the divergence between legal and economic conceptions of monopoly. Economics, primarily concerned with the fact of market control, has emphasized the control of price made possible by the exploitation of a mark or name. Extensive advertising expenditures may successfully differentiate in the minds of buyers the product of a given seller from those of his rivals. The more successful this differentiation the greater the control of the market it is possible for the seller to achieve, and, consequently, the more entrenched his monopoly position. But since there is no restriction of competition in the legal sense, the law, primarily concerned in trade mark and trade name cases with protection of intangible property interests, can see no element of monopoly. On the other hand, economic opinion does not proceed from the fact that there is a monopolistic significance in the use of a mark or name to the conclusion that this institution or practice is necessarily contrary to the public interest. ${ }^{27}$

It is fully consistent with the legal conception of the monopoly problem that the courts should enquire into the actual or probable results of agreements to restrain competition. But to do so would be to give up the traditional tests of monopolizing and to grapple with the problem of what is an unreasonable control of the market. The Appalachian Coals case $^{28}$ may indicate a tentative first step in this direction and somewhere between this and the Sugar Institute cases ${ }^{29}$ is to be found the indistinct dividing line between certain types of restrictions which are and are not at present considered to be in the public interest. The ways in which competition may be restrained or "regulated," however, are many, and if the courts are now willing to delve into the problems of market control they will have to rely more and more on economic analysis of the different types of control situations. The significance of market con-

27. See Handler, Unfair Competition (1936) 21 Iowa L. REv. 175, 185. For the views of an economist on these matters, see Chamberlin, Monopolistic Competition (1933) Appendix E.

28. Appalachian Coals, Inc. v. United States, 288 U. S. 344 (1933).

29. United States v. Sugar Institute, 297 U. S. 553 (1936), aff'g., 15 F. Supp. 817 (S. D. N. Y. 1934). For a thorough discussion of the problems, both legal and economic, raised by these cases, see Fly, Observations on the Anti-Trust Laws, Economic Theory and the Sugar Institute Decisions (1936) 45 YALE L. J. 1339, 46 id. 228. 
trols established through various kinds of open price quoting, basingpoint and zone price systems, agreements as to price terms and the like, are not apparent without a study of data hitherto considered by the courts to be irrelevant to the monopoly problem.

On the other hand, if economics is to be put itself in a position to contribute to the formulation of public policy, it must conceive the monopoly problem in a more extensive way than is at present customary. It is not enough to find evidence of the existence of market controls, nor is it sufficient to conduct purely analytical and descriptive studies of various types of control situations. While this is important, the formulation of public policy requires a distinction between situations and practices which are in the public interest and those that are not. And this requirement imposes the necessity of elaborating tests which can be applied by administrative bodies and by the courts. It is easy enough to present evidence of monopoly situations, which, to economics, is merely the absence of pure competition. The existence of price discrimination, of price rigidity, advertising expenditures, price leadership and other practices are sufficient to indicate the presence of monopoly elements. But these practices are hardly sufficient evidence of the presence or possibility of market controls adverse to the public interest. A further study of different types of industrial markets and business practices and of their effects on prices, outputs, investment and employment designed to indicate means of distinguishing between socially desirable and undesirable situations and practices may or may not be fruitful. It is, in any case, the only way in which economics can contribute directly to the shaping of public policy. A simultaneous movement by legal and economic thinking away from entrenched positions might be conducive to progress on this front. 